\title{
Expression of IL-1 family members upon stimulation with IL-17 differs in keratinocytes derived from psoriasis patients and healthy donors
}

\author{
P Muhr $^{1}$, J Zeitvogel ${ }^{1}$, T Werfel $^{1}$, M Wittmann ${ }^{1,2^{*}+}$ \\ From 5th European Workshop on Immune-Mediated Inflammatory Diseases \\ Sitges-Barcelona, Spain. 1-3 December 2010
}

\section{Background}

A number of studies have challenged the $T$ cell centred pathogenetic view of psoriasis by the finding that epithelium-expressed genes are intimately involved in the inflammatory process. IL-17 is an important inflammatory mediator in skin psoriasis.

\section{Objective}

IL-17 is known to act on keratinocytes and we were interested in its impact on expression of pro- and antiinflammatory IL-1 family members.

\section{Methods}

We compared human primary keratinocytes derived from psoriasis patients and healthy individuals using qRT-PCR and ELISA.

\section{Results}

In the presence of IL-17 psoriasis derived keratinocytes showed a significantly higher induction of the proinflammatory members IL-1F6 and IL-1F9 compared with those from healthy individuals but not of antiinflammatory members IL-1F5, IL-1F7 or IL-1F3. Both basal, as well as IL-17 induced production of IL-1F2/IL$1 \beta$ and IL-1F1/IL- $1 \alpha$ were found to be significantly lower in psoriasis keratinocytes.

\section{Conclusion}

As keratinocytes were derived from epidermal stem cells of the hair follicles and obtained from non-lesional sites, differences found are likely to present an intrinsic

\footnotetext{
† Contributed equally

${ }^{1}$ Dept. of Dermatology and Allergy, Division of Immunodermatology and

Allergy Research, Hannover Medical School, Hannover, Germany
}

Full list of author information is available at the end of the article feature of psoriasis epithelium. Our data suggest that the significance of IL-1 members as therapeutic targets in psoriasis conditions merits further and thorough investigation.

\section{Author details \\ ${ }^{1}$ Dept. of Dermatology and Allergy, Division of Immunodermatology and Allergy Research, Hannover Medical School, Hannover, Germany. ${ }^{2}$ Institute of Molecular and Cellular Biology, Faculty of Biological Sciences, University of} Leeds, Leeds, UK.

Published: 25 November 2010

doi:10.1186/1479-5876-8-S1-P19

Cite this article as: Muhr et al:: Expression of IL-1 family members upon stimulation with IL-17 differs in keratinocytes derived from psoriasis patients and healthy donors. Journal of Translational Medicine 2010 8(Suppl 1):P19.
Submit your next manuscript to BioMed Central and take full advantage of:

- Convenient online submission

- Thorough peer review

- No space constraints or color figure charges

- Immediate publication on acceptance

- Inclusion in PubMed, CAS, Scopus and Google Scholar

- Research which is freely available for redistribution 